\title{
PENINGKATAN HASIL BELAJAR TEKNIK PASSING DALAM PERMAINAN SEPAKBOLA MELALUI MEDIA AUDIOVISUAL DI MASA PANDEMI COVID-19 PADA SISWA SMP CITRA MULIA MAKASSAR
}

\author{
Muhammad Janwar ${ }^{1}$, Wahyu Munandar ${ }^{2}$, Suhardianto ${ }^{3}$ \\ 1,2,3 Universitas Megarezky \\ E-mail: janwarunimerz@gmail.com¹, wahyumunandar@universitasmegarezky.ac.id², \\ suhardianto@universitasmegarezky.ac.id ${ }^{3}$ \\ DOI: https://doi.org/10.36526/kejaora.v6i2.1481
}

\begin{abstract}
ABSTRAK
Penelitian ini bertujuan meningkatkan hasil belajar teknik passing dalam permainan sepakbola melalui media audiovisual Pada Siswa SMP Citra Mulia Makassar. Penelitian ini merupakan penelitian tindakan kelas (PTK) yang dilaksanakan sebanyak tiga kali pertemuan pada siklus I, dan 3 kali pertemuan di siklus II yang dirancang melalui empat tahap yaitu: 1) Perencanaan, 2) Pelaksanaan, 3) Observasi, dan 4) Refleksi. Subjek dalam penelitian ini adalah siswa kelas VIII SMP Citra Mulia sebanyak 25 orang. Pengambilan data menggunakan instrumen tes psikomotor, afektif dan kognitif dalam RPP. Indikator Keberhasilan pembelajaran mencapai $80 \%-100 \%$ ketuntasan secara Klasikal. Hasil akhir dari penelitian ini menunjukkan peningkatan hasil belajar passing dalam permainan sepakbola melalui media audiovisual dengan ketuntasan pada siklus I adalah 19 orang dengan persentase $76 \%$ dan terjadi peningkatan ketuntasan pada siklus II adalah 25 orang dengan persentase $100 \%$. Berdasarkan hasil penelitian ini dapat disimpulkan bahwa pembelajaran dengan menggunakan media audiovisual dapat meningkatkan hasil belajar passing dalam permainan sepakbola pada siswa SMP Citra Mulia Makassar.
\end{abstract}

Kata Kunci: Sepak Bola, Teknik Passing, Media Audiovisual.

\section{PENDAHULUAN}

Pendidikan Jasmani merupakan komponen pendidikan secara keseluruhan yang telah disadari oleh banyak kalangan. Tetapi dalam pelaksanaan pembelajaran pendidikan jasmani di sekolah belum efektif seperti yang diharapkan (Arifin, 2017). Selama ini terjadi penyempitan makna tentang mutu pendidikan yang hanya melibatkan kemampuan psikomotor atau keterampilan gerak saja. Pembekalan pengalaman belajar itu diarahkan untuk membina, sekaligus membentuk gaya hidup sehat dan aktif sepanjang hayat (Pahliwandari, 2016).

Proses pembelajaran pendidikan jasmani yang lebih diutamakan adalah pemahaman tentang karakteristik pertumbuhan dan perkembangan yang merata dari aspek belajar yaitu aspek kognitif yaitu aspek yang mencakup dalam hal pengetahuan atau wawasan, aspek afektif dalam hal ini berkaitan dengan sikap atau perilaku dan aspek psikomotor merupakan aspek yang berkaitan dengan keterampilan (skill). Pendidikan jasmani mengajarkan untuk mengembangkan pribadi bagi para peserta didik. Sumbangan yang tampak nyata untuk pengembangan keterampilan psikomotor (Suhardianto, 2021). Pendidikan jasmani merupakan pembelajaran yang memanfaatkan aktivitas jasmani yang dilakukan secara terstruktur yang bertujuan untuk mengembangkan kemampuan dan keterampilan individu secara kognitif, afektif perseptual, neuromuskuler (Melyza \& Aguss, 2021).

Sepak bola juga satu olahraga yang dimainkan di luar ruangan, olahraga ini dimainkan secara besar-besaran oleh dua kelompok yang disebut beregu. Setiap tim memiliki gawang dengan jaring, dan mereka saling berhadapan. Tujuannya adalah 
Jurnal Kejaora: Jurnal Kesehatan Jasmani dan Olah Raga

ISSN: 2541-5042 (Online)

ISSN: 2503-2976 (Print)

Volume 6 Nomor 2, Edisi November 2021

memasukkan bola ke dalam gawang lawan (Amin, 2020).

Sepakbola sangat digemari anakanak sampai kalangan orang dewasa sehingga olahraga sepakbola bisa menandingi kepopuleran dari cabang-cabang olahraga lainnya (Cakrawijaya \& Suhardianto, 2019). Sepakbola memiliki teknik dasar seperti passing (mengumpan), Shooting (Menendang), dribbling (menggiring), throwing (melempar bola), dan heading (menyundul) (Ramadan, 2017). Materi Sepak bola di SMP Citra Mulia Makassar sangat di sukai dan di gemari oleh para siswa, akan tetapi dilihat dari nilai hasil belajar passing yang diperoleh siswa sangat rendah. Passing merupakan teknik dasar yang paling sering digunakan dalam permainan sepakbola. Sebuah tim tangguh jika semua pemain dalam tim menguasai teknik dasar passing dengan baik (Hamdani et al., 2021).

Berdasarkan data awal yang diperoleh dari guru pendidikan jasmani olahraga kesehatan (PJOK) masih banyak siswa yang belum dapat mencapai nilai Kriteria Ketuntasan Minimal (KKM) yaitu 75 yaitu 16 orang dengan persentase $64 \%$ yang belum mencapai nilai KKM dan 9 orang dengan persentase $36 \%$ yang sudah mencapai nilai KKM sekolah SMP Citra Mulia Makassar.

Rendahnya hasil belajar siswa dalam materi passing dalam permainan sepakbola dipengaruhi oleh siswa harus belajar dari rumah karena masih dalam masa pandemi covid 19 sehingga siswa sulit untuk mendapatkan materi praktik dari proses pembelajaran via daring. Pembelajaran yang dilakukan oleh para siswa bukan karena perintah atau paksaan tetapi atas kemauan sendiri dalam mencoba, merasakan terhadap kegiatan yang dilakukan dalam berolahraga (Sukadi, 2021).

Dari permasalahan diatas solusi yang ingin diterapkan dalam penelitian ini adalah dengan menerapkan media audiovisual dalam proses pembelajaran daring. (Simbolon et al., 2021) mengemukakan bahwa "pembelajaran online di masa pandemi Covid-19 sangat cocok menggunakan media audiovisual siswa

mampu memahami materi pembelajaran dan dapat meningkatkan hasil belajarnya".

Media audiovisual adalah media yang mengeluarkan suara dan menampilkan gambar. Jenis media audiovisial lebih baik digunakan untuk pembelajaran karena dapat didengar dan dilihat (Ardyanto, 2018). Bagi guru media ini dapat digunakan sebagai bentuk pengembangan dari media pembelajaran yang berbentuk bahan ajar yang dapat membantu mempermudah penyampaian materi pembelajaran (Haris et al., 2018). Media audiovisual yang rencana diterapkan adalah video pembelajaran passing dalam permainan sepakbola yang dibuat dengan penjelasan teknik-teknik dasar di dalamnya. Media audiovisual ini bertujuan untuk meningkatkan hasil belajar passing dalam permainan sepakbola SMP Citra Mulia Makassar.

\section{METODE}

Adapun jenis penelitian yang digunakan adalah Penelitian tindakan kelas (PTK). penelitian tindakan kelas merupakan upaya dalam meningkatkan dan memperbaiki mutu pembelajaran dan hasil belajar peserta didik (Fitria et al., 2019).

\section{Subjek Penelitian}

Subjek dalam penelitian tindakan kelas ini adalah seluruh siswa kelas VIII SMP Citra Mulia Makassar yang berjumlah 25 orang siswa.

\section{Teknik Analisis Data}

Analisis data hasil penelitian mengenai peningkatan hasil belajar passing dalam permainan sepakbola melalui media audiovisual pada siswa SMP Citra Mulia Makassar, digunakan analisis kuantitatif. Data hasil tes pada siklus I dan siklus II secara kuantitatif. Berikut ini merupakan uraian tentang analisis data yang digunakan dalam penelitian tindakan kelas ini adalah data kuantitatif. Data kuantitatif berupa hasil belajar, dianalisis menggunakan teknik analisis deskriptif dengan ketuntasan belajar dan mean (rata-rata) kelas. Dengan demikian nilai ketuntasan belajar siswa diperoleh melalui rumus sebagai berikut : 
Jurnal Kejaora: Jurnal Kesehatan Jasmani dan Olah Raga

ISSN: 2541-5042 (Online)

ISSN: 2503-2976 (Print)

Volume 6 Nomor 2, Edisi November 2021

Tes psikomotor

$$
\text { Nilai }=\frac{\text { Jumlah Skor diperoleh }}{\text { Jumlah Skor Maksimal }} \times 100
$$

Tes Afektif

$$
\text { Nilai }=\frac{\text { Jumlah Skor diperoleh }}{\text { Jumlah Skor Maksimal }} \times 100
$$

Tes kognitif

$$
\text { Nilai }=\frac{\text { Jumlah Skor diperoleh }}{\text { Jumlah Skor Maksimal }} \times 100
$$

Nilai akhir yang diperoleh siswa :

Nilai Tes Psikomotor+Nilai Tes Sikap+Nilai Tes Afektif

3

Indikator Keberhasilan Pembelajaran

Indikator keberhasilan penelitian

tindakan kelas ini adalah terjadinya peningkatan hasil belajar passing siswa melalui media audiovisual siswa kelas VIII SMP Citra Mulia Makassar meningkat. Menurut Kriteria Ketuntasan Minimal (KKM) yang ditetapkan oleh pihak sekolah, standar ketuntasan minimal untuk tiap individu yaitu nilai 75 , dan mencapai tuntas secara klasikal 80\% dari jumlah siswa kelas VIII SMP Citra Mulia makassar.

\section{HASIL DAN PEMBAHASAN \\ Hasil Belajar Siklus I}

Kegiatan yang telah dilakukan pada siklus pertama adalah penyajian materi teknik dasar passing dalam permainan sepakbola melalui media audiovisual dilakukan sebanyak 2 kali pertemuan dan untuk kegiatan tes dilakukan pada pertemuan ke tiga atau pengambilan nilai aspek Psikomotor, Afektif dan kognitif. Berdasarkan hasil belajar pada siklus pertama, maka persentase ketuntasan belajar siswa kelas VIII SMP Citra Mulia Makassar dapat dilihat pada tabel dibawah ini:

Tabel 1. Deskripsi ketuntasan belajar siswa kelas VIII SMP Citra Mulia Makassar.

\begin{tabular}{llll}
\hline $\begin{array}{l}\text { Kriteria } \\
\text { ketuntasa } \\
\mathbf{n}\end{array}$ & $\begin{array}{l}\text { Kategor } \\
\mathbf{i}\end{array}$ & $\begin{array}{l}\text { Frekuens } \\
\mathbf{i}\end{array}$ & $\begin{array}{l}\text { Presentas } \\
\mathbf{i}\end{array}$ \\
\hline $75-100$ & Tuntas & 19 & $76 \%$ \\
\hline $0-74$ & $\begin{array}{l}\text { Tidak } \\
\text { Tuntas }\end{array}$ & 6 & $24 \%$ \\
\hline & Jumlah & 25 & $100 \%$ \\
\hline
\end{tabular}

Pada tabel diatas menunjukkan persentase ketuntasan hasil belajar siswa pada siklus pertama adalah $76 \%$ tuntas dari jumlah frekuensi 19 orang siswa dan $24 \%$ tidak tuntas dari jumlah frekuensi 6 orang siswa.

Berdasarkan hasil observasi dan evaluasi hasil belajar siswa selama pelaksanaan siklus I, siswa yang mencapai indikator keberhasilan secara klasikal yang telah dirumuskan sebelumnya yaitu $80 \%$ dari jumlah subjek yang diberikan tindakan, Sebagai bentuk refleksi yang menjadi pertimbangan dalam melakukan revisi tindakan pada siklus kedua yaitu :

a. Keterbatasan siswa yang mengikuti pembelajaran melalui media room zoom menjadi kendala dalam proses pembelajaran. 
b. Siswa dalam proses pembelajaran tidak fokus karena tidak dapat dipantau secara langsung.

c. Pelaksanaan pembelajaran praktek passing dalam permainan sepakbola masih kurang maksimal karena masih di masa pandemi sehingga pihak sekolah masih memberikan batasan untuk mengikuti pembelajaran secara offline/tatap muka.

\section{Hasil Belajar Siklus II}

Kegiatan yang telah dilakukan pada siklus kedua adalah penyajian materi teknik dasar passing dalam permainan sepakbola melalui media audiovisual dilakukan sebanyak 2 kali pertemuan dan untuk kegiatan tes dilakukan pada pertemuan ke tiga atau pengambilan nilai aspek Psikomotor, Afektif dan kognitif. Berdasarkan hasil belajar pada siklus kedua, maka persentase ketuntasan belajar siswa kelas VIII SMP Citra Mulia Makassar dapat dilihat pada tabel dibawah ini:

Tabel 2. Deskripsi ketuntasan belajar siswa kelas VIII SMP Citra Mulia Makassar.

\begin{tabular}{llll}
\hline $\begin{array}{l}\text { Kriteria } \\
\text { ketuntasan }\end{array}$ & Kategori & Frekuensi & Presentasi \\
\hline $75-100$ & Tuntas & 25 & $100 \%$ \\
\hline $0-74$ & $\begin{array}{l}\text { Tidak } \\
\text { Tuntas }\end{array}$ & 0 & $0 \%$ \\
\hline & Jumlah & 25 & $100 \%$ \\
\hline
\end{tabular}

Pada tabel diatas menunjukkan persentase ketuntasan hasil belajar siswa pada siklus kedua adalah $100 \%$ tuntas dari jumlah frekuensi 25 orang siswa dan tidak ada siswa yang tidak tuntas. Jadi hasil belajar teknik passing dalam permainan sepakbola siswa kelas VIII SMP Citra Mulia Makassar melalui media audiovisual pada siklus II mencapai persentase ketuntasan $100 \%$.

Refleksi pada siklus II, guru melaksanakan perbaikan pembelajaran untuk menyelesaikan permasalahan-permasalahan yang ada pada siklus I supaya yang dilakukan pada siswa mengalami peningkatan, berdasarkan hasil pengamatan sebagai berikut:

a. Siswa sudah aktif mengikuti proses pembelajaran dengan menggunakan media whatsapp dan melaksanakan tatap muka walaupun dalam pelaksanaanya siswa dibagi menjadi dua kelompok dan membedakan hari belajar setiap kelompoknya untuk mencegah penyebaran virus corona.

b. Dalam Proses pembelajaran siswa sudah fokus karena dapat dipantau secara langsung untuk memberikan koreksian atau teguran kepada siswa yang bermainmain dalam belajar.

c. Siswa dapat mempraktekkan langsung materi yang telah disampaikan oleh peneliti dengan praktek passing dalam permainan sepakbola.

d. Siswa sangat senang dalam proses pembelajaran tatap muka karena dapat mengeluarkan keterampilan gerak dalam proses pembelajaran.

\section{Perbandingan Hasil Belajar Siswa Pada Siklus I dan Siklus II}

Peningkatan hasil belajar siswa pada siklus I mencapai rata rata 74 sedangkan pada siklus II meningkat menjadi 85 . Untuk lebih jelasnya mengenai peningkatan hasil belajar passing dalam permainan sepakbola siswa kelas VIII SMP Citra Mulia Makassar, pada siklus I dan II dapat dilihat pada tabel dibawah ini:

Tabel 3. Deskripsi ketuntasan belajar murid pada siklus I dan II.

\begin{tabular}{|c|c|c|c|c|c|c|}
\hline \multirow[b]{2}{*}{ No } & \multirow[b]{2}{*}{ Kriteria Ketuntasan } & \multirow[b]{2}{*}{ Kategori } & \multicolumn{2}{|l|}{ Siklus I } & \multicolumn{2}{|l|}{ Siklus II } \\
\hline & & & Frekuensi & $\begin{array}{l}\text { Persentase } \\
(\%)\end{array}$ & Frekuensi & $\begin{array}{l}\text { Persentase } \\
\text { (\%) }\end{array}$ \\
\hline 1. & $75-100$ & Tuntas & 19 & 76 & 25 & 100 \\
\hline 2. & $0-74$ & Tidak Tuntas & 6 & 24 & 0 & 0 \\
\hline \multicolumn{2}{|c|}{ Jumlah } & & 25 & 100 & 25 & 100 \\
\hline
\end{tabular}


Jurnal Kejaora: Jurnal Kesehatan Jasmani dan Olah Raga

ISSN: 2541-5042 (Online)

ISSN: 2503-2976 (Print)

Volume 6 Nomor 2, Edisi November 2021

Dari Tabel 3 tampak bahwa dari 25 orang siswa kelas VIII SMP Citra Mulia Makassar yang menjadi subyek penelitian dapat diuraikan sebagai berikut:

a. Persentase ketuntasan belajar siswa setelah diberikan pembelajaran melalui media audiovisual, untuk kategori tuntas sebesar $76 \%$ pada siklus I, kemudian meningkat menjadi $100 \%$ pada siklus II untuk materi passing dalam permainan sepakbola.

b. Persentase ketuntasan belajar siswa setelah diberikan pembelajaran melalui media audiovisual, untuk kategori tidak tuntas sebesar $24 \%$ pada siklus I, kemudian menurun menjadi $0 \%$ pada siklus II.

Hal tersebut menunjukkan bahwa jumlah siswa yang berada dalam kategori tuntas mengalami peningkatan yakni, 19 orang atau $76 \%$ pada saat Siklus I proses ketuntasan terjadi dalam 2 kali pertemuan proses pembelajaran menggunakan media audiovisual dengan materi yang sama begitupun pada Siklus II mengalami ketuntasan $100 \%$ dengan pelaksanaan proses penelitian yang hampir sama dengan siklus I tetapi ditambah dengan beberapa media audiovisual yang lebih menarik lagi. Penelitian ini menunjukkan peningkatan ketuntasan kelas secara klasikal pada siklus II sebanyak $100 \%$ dan mencapai ketuntasan secara individu dengan nilai peserta didik berada pada kategori sangat baik.

\section{PEMBAHASAN}

Pembelajaran Siklus I dilakukan sebanyak 3 kali pertemuan dengan menerapkan pembelajaran melalui media audiovisual, berdasarkan hasil pembelajaran siklus I siswa SMP Citra Mulia Makassar masih ada siswa mengalami kesulitan melaksanakan pembelajaran sendiri di rumah karena proses pembelajaran di masa pandemi ini dilakukan secara online. Siswa masih belum terbiasa melakukan proses pembelajaran praktik secara online dan kurangnya akses internet yang bisa digunakan siswa dalam proses pembelajaran.

Berdasarkan tes hasil belajar siklus I terjadi peningkatan hasil belajar passing

dalam permainan sepakbola melalui media audiovisual pada siswa SMP Citra Mulia Makassar dari data awal yang jumlah siswa kategori tuntas hanya 9 orang dengan persentase $36 \%$ meningkat menjadi 19 orang dengan persentase $76 \%$. Dari hasil refleksi siklus I penelitian ini dilanjutkan ke siklus || karena belum mencapai indikator keberhasilan yaitu ketuntasan $80 \%$ secara klasikal.

Pembelajaran Siklus II juga dilakukan sebanyak 3 kali pertemuan dengan menerapkan pembelajaran melalui media audiovisual, berdasarkan hasil pembelajaran siklus II siswa SMP Citra Mulia Makassar sudah tidak mengalami kesulitan dalam proses pembelajaran karena dilakukan tatap muka sesuai dengan kebijakan dari pihak sekolah untuk dalam proses pembelajaran praktek dapat dilakukan dengan tatap muka dengan mematuhi protokol kesehatan saat berada dalam lingkungan sekolah.

Berdasarkan tes hasil belajar siklus II terjadi peningkatan hasil belajar passing dalam permainan sepakbola melalui media audiovisual pada siswa SMP Citra Mulia Makassar dari siklus I yang jumlah siswa kategori tuntas hanya 19 orang dengan persentase $76 \%$ meningkat menjadi 25 orang dengan persentase $100 \%$.

Keberhasilan dalam penelitian ini ditentukan dari peningkatan hasil belajar yang terjadi setiap siklusnya dan indikator keberhasilan pembelajaran pada siklus I $76 \%$ dan meningkat pada siklus II mencapai 100 $\%$. Hal ini berarti media audiovisual telah berhasil dalam meningkatkan hasil belajar passing dalam permainan sepakbola pada siswa SMP Citra Mulia Makassar.

Peningkatan hasil belajar yang terjadi pada siklus I dan II tidak lepas dari penerapan media audiovisual dalam proses pembelajaran. Media audiovisual merupakan pembelajaran yang sangat baik dilakukan di masa pandemi karena proses pembelajaran dapat dilakukan walaupun siswa tidak datang ke sekolah. Dimana video pembelajaran teknik dasar passing dikemas dalam bentuk video audiovisual yang diupload di youtube sehingga siswa dapat belajar mandiri dengan mengulang-ulang materi yang telah diberikan. Dengan menggunakan video 
Jurnal Kejaora: Jurnal Kesehatan Jasmani dan Olah Raga

ISSN: 2541-5042 (Online)

ISSN: 2503-2976 (Print)

Volume 6 Nomor 2, Edisi November 2021

pembelajaran dapat memberikan warna baru dalam proses pembelajaran serta dengan video dapat membantu guru dalam menyampaikan materi pembelajaran kepada peserta didik untuk meningkatkan hasil belajarnya (Kurniawan et al., 2017). Video merupakan pengganti guru dalam mengajar teori yang tidak bisa disampaikan di kelas dan memudahkan siswa dalam belajar materi yang diberikan karena dapat diulang-ulang oleh siswa dalam proses pembelajaran (Hamdani et al., 2021).

Hasil dari penelitian ini diperkuat dengan yang dilakukan (Kadek, 2020) dalam penelitiannya menyatakan bahwa "penerapan media pembelajaran audio visual berupa video pembelajaran dalam pembelajaran penjas materi teknik dasar sepakbola dapat meningkatkan aktifitas dan hasil belajar siswa kelas XI IPS 3 SMA Negeri 8 Gowa". (Prasetyo \& Setiabudi, 2017) Mengemukakan "bahwa terjadi peningkatan hasil belajar siswa dari aspek psikomotor, afektif dan kognitif dengan menggunakan media audiovisual".

Audovisual dapat merangsang otak siswa dalam belajar karena siswa merasa seperti menonton sebuah pertunjukan yang dapat dicontoh oleh siswa yang menonton video tersebut. Metode alat bantu media audiovisual dapat meningkatkan kemampuan dimana para siswa menjadi lebih aktif dalam belajar dan juga merasa lebih terbantu dengan menggunakan media audiovisual (Septiadi et al., 2019).

Dari hasil penelitian dapat disimpulkan bahwa melalui media audiovisual dapat meningkatkan hasil belajar passing dalam permainan sepakbola pada siswa SMP Citra Mulia Makassar dengan mencapai keberhasilan pembelajaran mencapai $100 \%$ pada siklus II.

\section{KESIMPULAN}

Berdasarkan hasil penelitian yang telah diuraikan maka dapat disimpulkan, penelitian tindakan kelas dengan judul "Peningkatan Hasil Belajar Passing dalam permainan sepakbola melalui media audiovisual pada siswa SMP Citra Mulia Makassar" menghasilkan kesimpulan sebagai berikut:

Metode audiovisual memiliki dampak positif dalam meningkatkan hasil belajar siswa yang ditandai dengan peningkatan ketuntasan belajar siswa setiap siklusnya. Hasil belajar passing dalam permainan sepakbola melalui media audiovisual pada siklus I siswa tuntas sebanyak 19 orang dengan persentase $76 \%$ dan pada siklus II terjadi peningkatan ketuntasan sebanyak 25 siswa dengan persentase $100 \%$.

\section{UCAPAN TERIMA KASIH}

Terima Kasih Kepada Kemendikbud yang telah membantu dalam membiayai penelitian ini dan ucapan terima kasih kepada LPPM Universitas Megarezky yang telah mendukung dalam pelaksanaan penelitian ini serta kepada seluruh pihak yang terlibat dalam proses penelitian ini.

\section{DAFTAR PUSTAKA}

Amin, A. A. (2020). Efektivita Belajar Menendang Bola Pada Permainan Sepakbola Melalui Modifikasi Alat Bantu Bola Plastik Pada Siswa Kelas VII.A SMP Hang Tuah Makassar. Eprints Universitas Negeri Makassar, $1(1), \quad 1-9$. http://eprints.unm.ac.id/18804/

Ardyanto, S. (2018). Peningkatan Teknik Servis Pendek Pada Bulutangkis Melalui Media Audio Visual. Jurnal IImiah Penjas, 4(3), 21-32. http://ejournal.utp.ac.id/index.php/JIP/ article/view/723

Arifin, S. (2017). Peran Guru Pendidikan Jasmani Dalam Pembentukan Pendidikan Karakter Peserta Didik. Multilateral Jurnal Pendidikan Jasmani Dan Olahraga, 16(1), 78-92. https://doi.org/10.20527/multilateral.v $16 \mathrm{i} 1.3666$

Cakrawijaya, M. H., \& Suhardianto. (2019). Metode Latihan Bervariasi Dapat Meningkatkan Kemampuan Dribling Sepakbola Siswa Smp Negeri 2 Borong Sinjai. Tadulako Journal Sport Sciences And Physical Education, 7, 11-18.

http://jurnal.untad.ac.id/jurnal/index.p $\mathrm{hp} / \mathrm{PJKR} / \mathrm{index}$

Fitria, H., Kristiawan, M., \& Rahmat, N. 
Jurnal Kejaora: Jurnal Kesehatan Jasmani dan Olah Raga

ISSN: 2541-5042 (Online)

ISSN: 2503-2976 (Print)

Volume 6 Nomor 2, Edisi November 2021

(2019). Upaya Meningkatkan Kompetensi Guru Melalui Pelatihan Penelitian Tindakan Kelas. Abdimas Unwahas, 4(1), 14-25. https://doi.org/10.31942/abd.v4i1.269 0

Hamdani, R., Santoso, N. P. B., \& Karisma, S. Y. (2021). Pengaruh latihan pass go dan drill passing terhadap tingkat akurasi passing dalam sepakbola pada anak usia 8-10 tahun ssb satria 11 jatipuro karanganyar tahun 2021. Jurnal IImiah Spirit, 21(2), 77-86.

Haris, F., Mukhtarsyaf, F., \& Liza. (2018). Pengembangan Model Belajar Motorik Berbasismedia Auto Visual Bagi Siswa Sdn Di Kecamatan Kuranji Padang. Jurnal Stamina, 1(1), 359369.

http://stamina.ppj.unp.ac.id/index.php/ JST/article/view/113

Kadek, H. (2020). Penerapan Media Pembelajaran Audio Visual Untuk Meningkatkan Hasil belajar Sepakbola Dalam Pembelajaran Penjas Siswa Negeri 8 Gowa. Sustainability (Switzerland), 4(1), 1-9. https://pesquisa.bvsalud.org/portal/re source/en/mdl-

20203177951\%0Ahttp://dx.doi.org/10. 1038/s41562-020-0887-

9\%0Ahttp://dx.doi.org/10.1038/s4156

2-020-0884-

z\%0Ahttps://doi.org/10.1080/1366987

7.2020.1758193\%0Ahttp://sersc.org/j ournals/index.php/IJAST/article/view/ 22

Kurniawan, R., Agung, A. . G., \& Tegeh, I. M. (2017). Pengembangan Video Pembelajaran Teknik Dasar Sepak Bola Dengan Konsep Quantum Learning. Jurnal Edutech Undiksha, $5(2)$, 179-188. https://ejournal.undiksha.ac.id/index.p $\mathrm{hp} / \mathrm{JEU} /$ article/view/20374

Melyza, A., \& Aguss, R. M. (2021). Persepsi Siswa Terhadap Proses Penerapan Pembelajaran Pendidikan Jasmani Olahraga Dan Kesehatan Pada Pandemi Covid-19. Journal Of Physical Education, 2(1), 8-16. http://jim.teknokrat.ac.id/index.php/pe ndidikanolahraga/article/view/950

Pahliwandari, R. (2016). Penerapan Teori Pembelajaran Kognitif dalam Pembelajaran Pendidikan Jasmani dan Kesehatan. Jurnal Pendidikan Olahraga, 5(2), 154-164. https://journal.ikippgriptk.ac.id/index.p hp/olahraga/article/view/383

Prasetyo, M. S., \& Setiabudi, M. A. (2017). Peningkatan Hasil Belajar Passing Menggunakan Kaki Bagian Dalam Pada Pembelajaran Sepakbola Dengan Audiovisual. Jurnal Kejaora, 2(2), 29-43.

Ramadan, G. (2017). Pengaruh Metode Pembelajaran Dan Motivasi Belajar Terhadap Hasil Belajar Passing Sepakbola. JUARA : Jurnal Olahraga, 2(1), 1. https://doi.org/10.33222/juara.v2i1.27

Septiadi, W., Sungkawa, M. G. G., \& Taufik, M. S. (2019). Peningkatan keterampilan shooting kaki bagian dalam melalui audio-visual. Jurnal Maenpo: Jurnal Pendidikan Jasmani Kesehatan Dan Rekreasi, 09(1), 1-7.

Simbolon, M. E. M., Lestari, N., Monica, Armanto, T., \& Alfarras, B. (2021). Efektivitas Pembelajaran PJOK Menggunakan Media Audio Visual saat Pandemi Covid-19 di Bangka Belitung. Jurnal Pendidikan Olahraga, 4(1), 1-8.

Suhardianto. (2021). Peningkatan Hasil Belajar Servis Backhand Dalam Permainan Bulu Tangkis Melaui Metode Inquiry Pada Siswa Smp Negeri 4 Ponrang Kabupaten Luwu. Indonesian Journal of Physical Activity, $\quad 1(1), \quad 1-13$. https://www.ijophya.org/index.php/ijop hya/article/view/4

Sukadi. (2021). Penerapan Model Pembelajaran Role Playing Dapat Meningkatkan Prestasi Belajar Penjaskes Dalam Sepak Bola Pada Siswa Kelas VII B SMP Negeri 2 Karangjati Kabupaten Ngawi Tahun Pelajaran 2019/2020. Jurnal Merdeka Mengajar, 2(2), 43-49. https://ejurnalkotamadiun.org/index.p $\mathrm{hp} / J M M / a r t i c l e / v i e w / 771$ 